\title{
Cytokeratin-containing cells in proliferative diabetic retinopathy membranes
}

\author{
P Hiscott, R Gray, I Grierson, Z Gregor
}

Unit of Ophthalmology, Department of Medicine, University of Liverpool

P Hiscott

I Grierson

Oxford Eye Hospital

R Gray

Moorfields Eye Hospital, London

Z Gregor

Correspondence to: Dr P Hiscott, Unit of Ophthalmology, Department of Medicine, University of Liverpool, PO Box 147, Liverpool L69 3BX.

Accepted for publication 23 September 1993

\begin{abstract}
Immunohistochemical techniques were used to investigate the relation between retinal pigment epithelial cells (RPE), traction retinal detachment (TRD) membranes, and combined traction rhegmatogenous retinal detachment (CTR) membranes in proliferative diabetic retinopathy. Seven CTR and five TRD membranes were obtained during closed microsurgery. Six of the seven CTR membranes and one of the five TRD membranes contained RPE. Eleven of the 12 diabetic membranes incorporated glial cells. The findings emphasise that the intravitreal membranes of proliferative diabetic retinopathy contain a diversity of cell types and indicate that RPE tend to contribute to CTR, rather than TRD, membranes. The histopathological appearance of CTR membranes is that of a hybrid between TRD and proliferative vitreoretinopathy membranes.
\end{abstract}

(Brf Ophthalmol 1994; 78: 219-222)

The epiretinal and posterior hyaloid membranes of proliferative diabetic retinopathy (PDR) are essentially fibrovascular in composition, although it is well established that the membranes contain glial and inflammatory cells. ${ }^{1-6}$ On the other hand, the place of retinal pigment epithelial cells (RPE) in PDR membranes is more contentious. While many investigators have not observed RPE in PDR membranes, ${ }^{157-9}$ evidence that RPE may contribute to the membranes has been produced by some immunohistochemical and transmission electron microscopic studies. ${ }^{210-12}$ For example, an ultrastructural investigation by Hamilton et $a l^{2}$ identified cells of probable RPE origin in PDR membranes from eyes with previous retinal detachment. The findings of Hamilton and coworkers suggest that RPE become involved in PDR membranes when there is an associated rhegmatogenous retinal detachment.

Rhegmatogenous retinal detachment usually

antibodies which recognise a spectrum of cytokeratins because mammalian RPE have been shown to express a range of cytokeratins in vivo and in vitro. ${ }^{15-22}$ In addition, we compared the distribution of RPE in the membranes with the location of glial cells (detected by immunostaining the glial cytoskeletal protein glial fibrillary acidic protein - GFAP) in the specimens since retinal glia are the other prominent non-vascular cell type found in PDR membranes. ${ }^{1-6}$ The results of the immunohistochemical studies were correlated with the clinical appearances of the retina in the eyes from which the membranes were removed.

\section{Materials and methods}

Twelve vascularised PDR membranes were obtained during closed pars plana vitrectomy for tractional complications of proliferative diabetic retinopathy and grouped into CTR (seven) or TRD (five) membranes.

The specimens were fixed for between 4 and 48 hours in $10 \%$ formol saline, dehydrated in graded concentrations of ethanol, and embedded in paraffin wax. Sections $6 \mu \mathrm{m}$ thick of the wax embedded tissue blocks were immunostained for cytokeratins with a keratin wide screening rabbit antiserum (Dako, High Wycombe, UK). This antibody detects a broad range of cytokeratins including cytokeratin 8 (which is present in reactive and in situ RPE) ${ }^{17-21}$ as well as several other cytokeratin subtypes thought to be more variably displayed by RPE (for example, 5, 6, and 16). ${ }^{17}$ The antiserum was chosen to minimise false negative staining of RPE cells in tissues. Alternate tissue sections were immunostained for GFAP using an antiserum from Sigma (Poole, UK) or employed in procedural controls, including processing after absorption of the primary antibody with purified antigen. The immunoperoxidase technique was used as previously described ${ }^{1523}$ with the peroxidase substrate 3-amino-9-ethylcarbazole (AEC) which yielded a pink/red reaction product. Some sections were counterstained with Mayer's haematoxylin. In addition, some sections were stained with haematoxylin and eosin rather than immunohistochemically.

Sections were examined by bright field and differential interference contrast microscopy. The distribution and approximate percentage of cells staining positively for cytokeratin or GFAP were recorded as described previously. ${ }^{1523}$ whereas TRD membranes may not incorporate RPE.

To investigate the relation between RPE, TRD, and CTR membranes we studied CTR and TRD membranes employing immunohistochemical markers to the family of cytoskeletal proteins known as cytokeratins. ${ }^{1516}$ We used

\section{Results}

Seven of the PDR membranes contained cells which were immunoreactive for cytokeratins (Table 1, Figs 1 and 2) and this immunore- 
Table 1 Immunohistochemistry of 12 proliferative diabetic retinopathy membranes

\begin{tabular}{llllll}
\hline $\begin{array}{l}\text { Specimen } \\
\text { number }\end{array}$ & $\begin{array}{l}\text { Nature of } \\
\text { subjacent retinal } \\
\text { detachment }\end{array}$ & $\begin{array}{l}\text { CK positive } \\
\text { cells(\%) }\end{array}$ & $\begin{array}{l}\text { Distribution of } \\
\text { CK positive cells }\end{array}$ & $\begin{array}{l}\text { GFAP positive } \\
\text { cells (\%) }\end{array}$ & $\begin{array}{l}\text { Distribution of } \\
\text { GFAP } \\
\text { positive cells }\end{array}$ \\
\hline 1 & CTR & $+(20)$ & Layers/I & $+(10)$ & Foci/layers \\
2 & CTR & $+(20)$ & Layers/I & $+(5)$ & Foci \\
3 & CTR & $+(15)$ & Foci/layers/I & $+(15)$ & Foci \\
4 & CTR & $+(5)$ & Foci/I & $+(20)$ & Layers/I \\
5 & CTR & $+(5)$ & Foci/layers/I & $+(10)$ & Foci/layers/I \\
6 & CTR & $+(5)$ & Layers & $+(5)$ & Layers \\
7 & CTR & $-(0)$ & N/A & $+(10)$ & Layers \\
8 & TRD & $+(10)$ & Foci & $+(10)$ & Layers \\
9 & TRD & $-(0)$ & N/A & $+(15)$ & Foci/layers \\
10 & TRD & $-(0)$ & N/A & $+(5)$ & Foci \\
11 & TRD & $-(0)$ & N/A & $+(5)$ & Layers \\
12 & TRD & $-(0)$ & N/A & $-(0)$ & N/A \\
\hline
\end{tabular}

$\mathrm{CK}=$ cytokeratin; $\mathrm{GFAP}=$ glial fibrillary acidic protein; $\mathrm{CTR}=$ combined traction rhegmatogenous retinal detachment; TRD = traction retinal detachment; $I=$ isolated cells; $a=$ full thickness macular hole; N/A=not applicable; $+=$ present; $-=$ absent.

activity was absent in sections processed in procedural controls: for example, after absorption of the primary antibody with purified antigen (Fig lb). Six of the cytokeratin positive biopsies were from CTR membranes and only one of the membranes which included cytokeratin positive cells was a TRD membrane
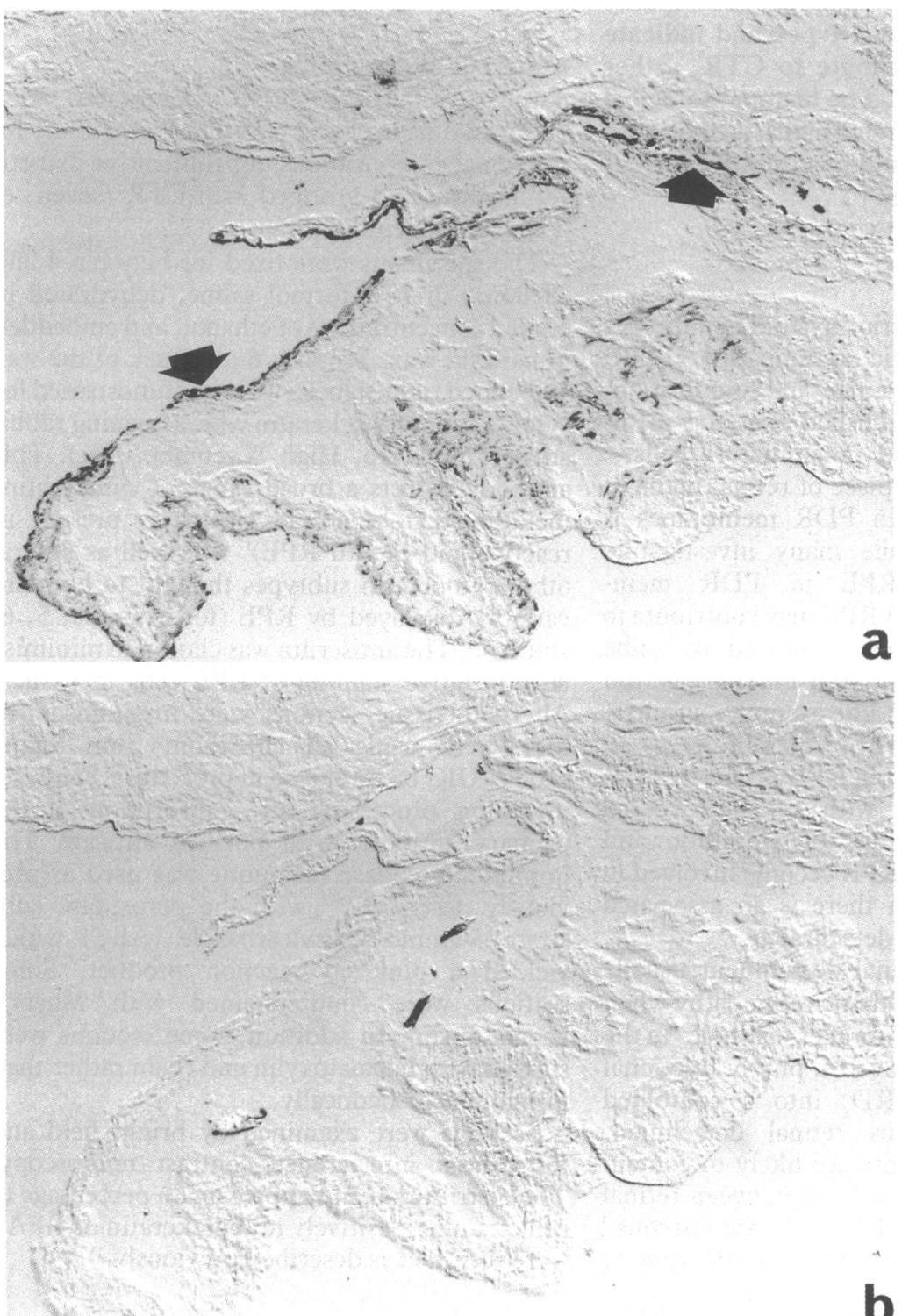

Figure 1 Differential interference contrast micrographs of serial sections of a combined traction rhegmatogenous retinal detachment membrane (a) stained with the immunoperoxidase technique for cytokeratins (no counterstain). Note the prominent layers of cytokeratin positive cells (arrows). (b) Labelled with the same method as in (a) but following absorption of the primary antibody against purified antigen. No immunostaining is seen. Magnification $\times 95$.
(Table 1). Conversely, only one of the five PDR membranes which were cytokeratin negative was a CTR membrane (Table 1). The association between CTR membranes and the presence of RPE in the biopsies was significant (using the non-parametric sign test which tests the significance of presence or absence of a parameter; $\alpha=0 \cdot 1)$. The estimated RPE contribution ranged from $20 \%$ to $5 \%$ of the cells in the cytokeratin positive membranes (Table 1). The cytokeratin positive cells were aggregated in layers and/or foci (often at apparent tissue surfaces) in the specimens and, in addition, five of the membranes also contained scattered, isolated cells which stained for cytokeratin (Table 1, Figs 1 and 2).

Eleven of the 12 membranes contained cells which were immunoreactive for GFAP (Table 1, Fig 2). No significant difference could be detected between CTR and TRD membranes with regard to the glial content of the specimens. As with the RPE, the estimated GFAP positive cell contribution ranged from $20 \%$ to $5 \%$ (Table 1) and glial cells also were arranged in layers and/ or foci (again, often at tissue margins). Two specimens incorporated isolated glial cells (Table 1). In some specimens glial aggregates were adjacent to RPE clusters (Fig 2). However, in general, no overall relationship (either in distribution or proportion of cells present) was detected between RPE and glial groups. Colabelling of cell aggregates for GFAP and cytokeratin was not observed.

In addition to RPE and glia, the membranes contained fibrovascular tissue and a variable number of scattered inflammatory cells.

\section{Discussion}

The results emphasise that PDR membranes contain a variety of cell types. In keeping with reports of previous studies, ${ }^{1-6}$ glial cells were present in the vast majority of the diabetic membranes in our investigation. In addition, half of our specimens incorporated RPE whereas RPE were not cited as a component of proliferative diabetic retinopathy membranes in many earlier accounts. ${ }^{157-9}$ Although the previous studies may have been restricted to TRD membranes, the findings of our investigation suggested that the contribution of RPE to proliferative diabetic retinopathy membranes has been underestimated.

We found that the vast majority of RPE containing biopsies were from CTR membranes. Indeed, the correlation between CTR membranes and cytokeratin positive cell content compares favourably with the association between RPE and membranes of proliferative vitreoretinopathy. ${ }^{15}$ However, proliferative vitreoretinopathy membranes tend to include a higher percentage of RPE than do CTR membranes: up to $90 \%$ of proliferative vitreoretinopathy membrane cells may be RPE ${ }^{15}$ whereas in the present study no more than $20 \%$ of the CTR membrane cells are cytokeratin positive.

The finding that most proliferative diabetic retinopathy membranes which contain cytokeratin positive cells are CTR membranes suggests that a retinal break is an important factor in 


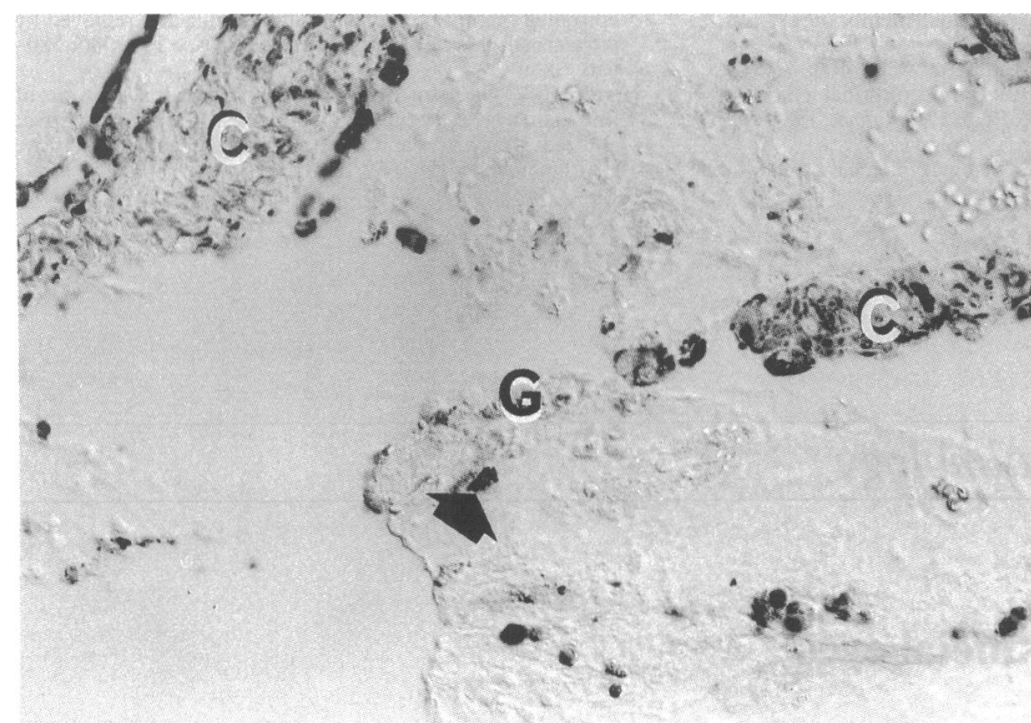

a

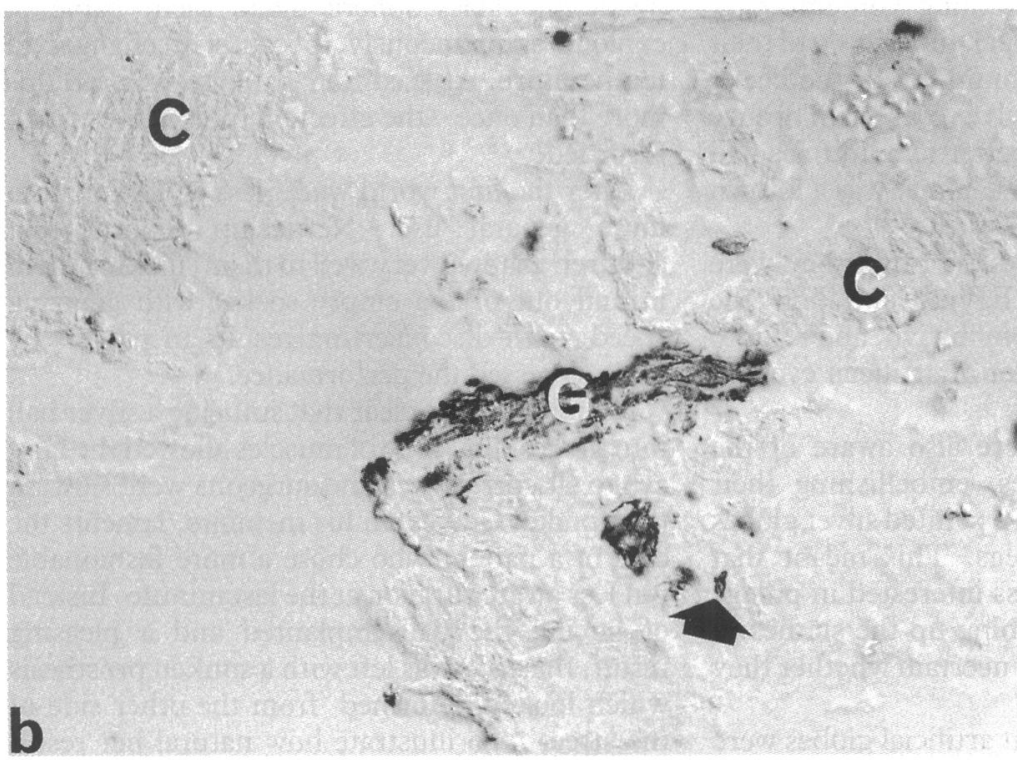

Figure 2 Sections from a combined traction rhegmatogenous retinal detachment membrane stained with the immunoperoxidase method for $(a)$ cytokeratins and $(b)$ glial fibrillary acidic protein $(G F A P)$. Layers and foci of cells are immunoreactive for either cytokeratins $(C)$ or GFAP $(G)$. Pigment is also seen in the tissues (arrows). No counterstain. Magnification $\times 190$.

permitting RPE access to proliferative diabetic retinopathy membranes. Nevertheless, one RPE-containing proliferative diabetic retinopathy membrane was removed from an eye with a purely tractional detachment. Although it is possible that a small retinal hole was not detected at surgery in this TRD membrane, there is evidence that RPE can migrate through intact neuroretina to the vitreous cavity. ${ }^{1624}$ For example, RPE have been reported in idiopathic and post-inflammatory epimacular membranes ${ }^{24}$ while vitreous membrane formation in rabbits may be associated with RPE migration through the retina. ${ }^{16}$

RPE and glia tended to be clustered into layers or foci of cytokeratin or GFAP positive cells respectively. However, the location of RPE and glial cells appeared very variable with respect to each other suggesting that the distribution of these two cell types was not dependent on each other. In addition, we did not observe colabelling of aggregated cells for cytokeratins and GFAP. Coexpression of the two intermediate filament proteins has been found in a small subpopulation of epiretinal membrane cells by Vinores and colleagues. ${ }^{22}$ Vinores used resin embedded specimens with immunogold techniques $^{22}$ : methods which were substantially different from our approach and which may have accounted for the differences in results between the two studies.

Presumably the CTR membranes originally were typical fibrovascular TRD membranes which, by virtue of tractional events, caused a retinal tear and subsequently acquired an RPE component. The migration and proliferation of RPE in ostensibly post-contractile proliferative diabetic retinopathy membranes underlines the protracted development of intravitreal membranes compared with skin wounds. ${ }^{25}$ Moreover, the late acquisition of RPE gives CTR membranes the histopathological appearance of a hybrid between TRD and proliferative vitreoretinopathy membranes.

This work was funded by the Foundation for the Prevention of Blindness.

1 Kampik A, Kenyon KR, Michels RG, Green WR, de la Cruz ZC. Epiretinal and vitreous membranes. Comparative study of 56 cases. Arch Ophthalmol 1981; 99: 1445-54.

2 Hamilton CW, Chandler D, Klintworth GK, Machemer R. A transmission and scanning electron microscopic study of surgically excised preretinal membrane proliferations in diabetes mellitus. Am F Ophthalmol 1982; 94: 479-88.

3 Green WR. Retina. In: Spencer WH, ed. Ophthalmic pathology: an atlas and textbook. 3rd ed. Philadelphia: Saunders, 1985: 589-1291.

4 Jerdan JA, Michels RG, Glaser BM. Diabetic preretinal membranes: an immunohistochemical study. Arch Ophthalmol 1986; 104: 286-90.

5 Garner A. Retinal angiogenesis: mechanisms in health and disease. Sem Ophthalmol 1987; 2: 71-80.

6 Ohira A, de Juan E. Characterisation of glial involvement in proliferative diabetic retinopathy. Ophthalmologica 1990 ; 201: 187-95.

7 Clarkson JG, Green WR, Massof D. A histopathologic review of 168 cases of preretinal membrane. Am 7 Ophthalmol 1977 ; 84: 1-17.

8 Jerdan JA, Pepose JS, Michels RG, Hayashi H, de Bustros S, Sebag M, et al. Proliferative vitreoretinopathy membranes an immunohistochemical study. Ophthalmology 1989; 96: 801-10.

9 Kwak SI, Chung H, Lee J. Cellular components of proliferative vitreoretinal membranes. Korean $\mathcal{F}$ Ophthalmol 1991; 5 : 68-75.

10 Smith RS, van Heuven WAJ, Streeten B. Vitreous membranes: a light and electron microscopic study. Arch Ophthalmol 1976; 94: 1556-60.

11 Weller M, Esser P, Heimann K, Weidemann P. Retinal microglia: a new cell in idiopathic proliferative vitreoretinomicroglia: a new cell in idiopathic prolifer

12 Molitor R, Esser P, Weller M, Wiedemann P, Heimann K. Kontraktile elemente bei proliferativen netzhauterkrankungen. Ophthalmologe 1992; 89: 34-8.

13 McLeod D. Closed microsurgery for advanced diabetic eye disease. In: Kanskii JJ, Morse PH, eds. Disorders of the vitreous, retina and choroid. London: Butterworths, 1983: 176-209.

14 Machemer R. Pathogenesis and classification of massive periretinal proliferation. Br $\mathcal{F}$ Ophthalmol 1978; 62: 737-47.

15 Hiscott PS, Grierson I, McLeod D. Retinal pigment epithelial cells in epiretinal membranes: an immunohistochemical cells in epiretinal membranes: an imm
study. Brf Ophthalmol 1984; 68: 708-15.

study. Brf Ophthalmol 1984; 68: 708-15.
16 Hitchins CA, Grierson I. Intravitreal injection of fibroblasts: the pathological effects on the ocular tissues of the rabbit following an intravitreal injection of autologous skin fibroblasts. Br f Ophthalmol 1988; 72: 498-510.

17 McKechnie NM, Boulton M, Robey HL, Savage FJ, Grierson I. The cytoskeletal elements of human retinal pigmen epithelium: in vitro and in vivo. $\mathcal{F}$ Cell Sci 1988; 91 : 303-12. 18 Owaribe K, Kartenbeck J, Rungger-Brandle E, Franke WW. Cytoskeletons of retinal pigment epithelial cells: interspecies differences of expression patterns indicate independence of cell function from the specific complemen

proteins. Cell Tissue Res 1988; 254: 301-15.
19 Kasper M, Moll R, Stosiek P, Karsten U. Patterns of cytokeratin and vimentin expression in the human eye. Histochemistry 1988; 89: 369-77.

20 Robey HL, Hiscott P, Grierson I. Cytokeratins and retinal epithelial cell behaviour. $\mathcal{F}$ Cell Sci 1992; 102: 329-40.

21 Fuchs U, Kivela T, Tarkkanen A. Cytoskeleton in normal and reactive human retinal pigment epithelial cells. Invest reactive human retinal pigment epi
Ophthalmol Vis Sci 1991; 32:3178-86.

22 Vinores SA, Van Niel E, Kim HJ, Campochiaro PA. Simultaneous expression of keratin and glial fibrillary acidic 
protein by the same cells in epiretinal membranes. Invest Ophthalmol Vis Sci 1992; 33: 3361-6.

23 Hiscott PS, Grierson I, Trombetta CJ, Rahi AHS Marshall J, McLeod D. Retinal and epiretinal glia - an immunohistochemical study. Br $\mathcal{f}$ Ophthalmol 1984; 68: 698-707.

24 Michels RG. A clinical and histopathological study of epiretinal membranes affecting the macula and removed by vitreous surgery. Trans Am Ophthalmol Soc 1982; 80: 580 656.

25 Hiscott PS, Grierson I, McLeod D. Natural history of fibrocellular epiretinal membranes: a quantitative, autoradiographic and immunohistochemical study. Brf Ophthalmol 1985; 69: 810-23.
Artificial eyes - not something contemporary ophthalmologists spend much time on - had their origins in Egypt, where mummies of the better class had enamel covered silver eyes, with bronze lids. (The fact that more geriatric mummies had white pupils confirms that cataract was a known entity.)

This doesn't necessarily mean that they were used for the living in Egypt, although the Romans certainly used them in vivo, and refer to the 'faber ocularius' (maker of artificial eyes) in inscriptions.

The ancient Greeks were also aware of the principle of artificial eyes, embellishing their more important statues with painted silver globes held in place by gold pegs. This meant that invading Spartans were less interested in pillage and violence than in climbing up the statues to steal the eyes. Again, it is uncertain whether they used them for the living.

We know for certain that artificial globes were being worn by 1561 . Pare (who was in disgrace for running out of boiling oil as an army surgeon, until he found that it didn't work anyway) mentions artificial eyes, but gives little detail of their manufacture. And in a play written in 1617, a woman who has rejected a one eyed suitor is admonished with the phrase 'what does it matter - he can have a silver one put in!'. The first English 'faber ocularis' set up in Ludgate Hill in 1681, advertising enamel artificial eyes 'so exact as to look natural', which were also 'very ornamental and commodious'.

But around 1917, the burgeoning 'artificial eye' industry suffered a setback, when its product - greatly needed for injured soldiers returning from the war - came under the Defence of the Realm regulations. They were required to send the Director of Optical Munitions and Glassware 'returns of the number and material of all eyes under their control'.

In point of fact, some of these false eyes proved pretty well un-controllable, as the partial vacuum inside the glass sphere made them liable to explode spontaneously, because of changes in temperature. At least four patients suffered this more than once - the effect on their nerves is not recorded!

After the first world war, glass eyes came into more general use. Nettleship reports that children adapted very well to them, flicking them in and out of the empty socket with amazing speed, with disconcerting results in passers by who witnessed the performance.

Although it was clear that suturing a silver ball into the residual cone of muscles allowed the false eye to sit correctly, some surgeons were slow on the uptake. Graves, in his memoirs, laments the case of a patient who chose a more fashionable but less aware surgeon at the last minute. Instead of having the ball implanted and a pleasing result, this lady was left with a sunken prosthesis which looked deformed 'from the other side of the street'. To illustrate how natural her result could have looked, Graves mentions a nurse who completed the whole of her training without anyone suspecting she wore a prosthesis.

However, the strangest use of a glass eye was reported in the $B F O$ in 1911 , when at the trial of the Camorrhist secret society in Italy, the accused wished to interrupt his cross examination. 'Becoming wildly excited, he took out his glass eye and threw it on the floor of the court.' His face, apparently, presented a 'horribly disfigured' appearance, and his questioner duly fainted.

FIONA ROMAN

Bruce GM. The ancient origins of artificial eyes. Annals of Medical

History.
Camorrhist's glass eye. Notes and Echoes. Br $\mathcal{F}$ Ophthalmol 1911; 9: 547 .

Glass eyes. Notes and echoes. Br f Ophthalmol 1938; 22: 445.

Graves B. Rational medicine. London: Nicholson and Watson, 1944: 52 .

Nettleship E. The diseases of the eye. London: Churchill, 1890:

Rochester AS. The spontaneous explosion of Snellen improved artificial eyes. Brf Ophthalmol 1921; 5: 522-3. 